\title{
Yield and yield attributes of cotton to foliar application of nutrients under rainfed condition
}

K.R. MALODE, D.B. TAMGADGE, N.D. RATHOD AND N.D GHUBE

MEMBERS OF RESEARCH FORUM:
Corresponding author :
K.R. MALODE, Department of Soil
Science and Agricultural Chemistry,
College of Agricuture (VNMKV)
NAIGAON (M.S.) INDIA
Email: munna.acss@ gmail.com

Co-authors :

N.D. RATHOD AND N.D GHUBE, Department of Soil Science and Agricultural Chemistry, College of Agricuture (VNMKV) NAIGAON (M.S.) INDIA

D.B. TAMGADGE, Department of Soil Science and Agricultural Chemistry, College of Agriculture, NAGPUR (M.S.) INDIA

Received : 23.08.2014; Revised : 24.10.2014; Accepted : 11.11 .2014

\section{Summary}

A field experiment was conducted during Kharif season of 2007-08 at Extra Assistant Director (EAD) Farm, College of Agriculture, Nagpur. The field experiment was laid out in Randomized Block Design with ten treatments replicated thrice to find out the response of cotton to foliar application of nutrient under rainfed condition. Foliar application of 2 per cent urea and 2 per cent DAP significantly increased seed cotton yield, number of open bolls/plant, boll weight, N, P and K Nutrient content, uptake, fibre quality parameters i.e. ginning percentage, fibre strength and oil per cent.

Key words : Foliar application, Nutrient content and uptake, Quality parameters

How to cite this article : Malode, K.R., Tamgadge, D.B., Rathod, N.D. and Ghube, N.D. (2014). Yield and yield attributes of cotton to foliar application of nutrients under rainfed condition. Asian J. Soil Sci., 9(2): 261-264. 